\title{
The effect of portable MQL applicator onto carbide insert during turning
} Inconel 718

\author{
Azreen Zainol ${ }^{1}$ and M.Z.A Yazid ${ }^{2 *}$ \\ ${ }^{1,2}$ UniKL IPROM, 119 Jalan7/91, Taman Shamelin Perkasa, 3.5 Miles Cheras, \\ 56100 Kuala Lumpur. \\ *Email: mzaiday@unikl.edu.my \\ Phone: +60391795000; Fax: +60391795001
}

\begin{abstract}
Turning operations are a versatile secondary metal cutting process. In metal cutting industry, manufacturing processes are designed to attain minimum manufacturing cost, best quality and improved cutting tool's performance. Nonetheless, the deterioration of cutting tools, occupational diseases amongst the workers and environmental aspects are increasingly becoming a major issue. Therefore, one alternative to reduce the impact of metal cutting activity in term of cutting tool, the health and environment is Portable MQL Applicator. The portable MQL applicator is an equipment that equipped with pneumatic system to deliver a small amount of fluid in the form of aerosol into the cutting zone. The effect of the portable MQL applicator was investigated and compared with the results from dry machining in terms of tool life and material removal rate in turning of Inconel 718 using carbide tool. The results showed that the applications of the portable MQL applicator have successfully resulted in better tool life and improved material removal rate.
\end{abstract}

Keywords: Turning; metal cutting; minimum quantity lubrication; MQL applicator.

\section{INTRODUCTION}

Turning is a one of the most broadly employed machining operation. In turning operation, the heat is generated in the cutting zone due to the friction develop between tool-chip and tool-work interfaces. The generated heat strongly affects the tool life, surface quality, cutting force and cutting temperature. Application of cutting fluids in machining operation is essential and its application enhances tool life, surface quality and reduce cutting forces and cutting temperature [1]. A large amount of coolant utilization in the industry causes adverse effects on the health of workers who are engaged in daily machining processes. It also contributes to the high disposal costs of the used lubricants [2]. Several techniques have been investigated to deal with these disposal costs, including fluid maintenance schedules to extend the fluid life. Recycling programs to reuse the fluids and dry machining to completely eliminate the cutting fluid has also been approached $[3,4]$. Nevertheless, these techniques are expensive in terms of both recycling and application. Thus, there are continuous endeavors to discover a replacement for these cutting fluids. The Minimum Quantity Lubrication (MQL), also called Near to Dry Machining or Micro-Lubrication, is an approach which sprays a small amount of fluid about the range of 10 to $100 \mathrm{ml} / \mathrm{h}$ in the form of aerosol to the cutting zone area with the support of compressed air [5-7]. It is an appropriate approach 
for lubrication and effective in machining [8]. The MQL advantages includes reduction of cutting fluid amount, less operating cost, prolong the tool life and improved surface quality [3]. Besides that, it also provides better and healthier with less environmental pollution, oxidation and storage stability [9]. This approach offers simple, economical and environmentally friendly alternatives.

Currently available MQL equipment is expensive and uses complex fluid-flow system. The portable MQL applicator is developed by the authors to suit to almost all metal cutting processes, in particular for turning operation. The advantages of the portable MQL applicator include simply flow system, low cost and easy maintenance with no complex part. An experimental study has been conducted to investigate the effectiveness of the portable MQL applicator and dry machining in turning of Inconel 718 using TiAIN coated carbide. Two aspects of output parameter were investigated namely tool life and material removal rate under turning operation.

\section{CONCEPT AND WORKING PRINCIPLE}

Portable MQL applicator was based on the principle that a drop of fluid is split by an air flow, distributed and transported in the same direction of the airflow. It applies purely pneumatic concept to make the system works. Figure 1 demonstrates a schematic diagram of the MQL applicator components. Basically, the mixture of pressurized air and lubricant fluid droplets is applied directly to the interface between the tool and the chips of the workpiece. A small amount of fluid, formulated based on biodegradable fluid, drops from the reservoir, located on top of the equipment, through rubber-tube to the nozzle spray directed to the tool and workpiece interface. The flow is supported by a compressed air which results in aerosol form. The number of fluid droplets from the reservoir can be adjusted manually on the flow speed control or 3-2 hand valve. The air pressure can also be measured and indicated using the air regulator. The equipment is equipped with three flexible rubber-tube that allow user to position the nozzle in any orientation.

The application of three flexible nozzles on portable MQL applicator is based upon the theory of metal machining. This theory is parallel with the principal role to carry away the heat from the three main sources of heat during the machining. The main sources of heat are the primary or shear zone and secondary zone or tool-work piece interface and tertiary zone as exhibited in Figure 2 [10-12]. Primary zone generates the larger amount of heat. The generation of heat occurs because there is a plastic deformation of the work piece. At the secondary zone, heat is generated because of the friction between chip and tool face. At tertiary zone, the heat is generated due to friction between the tool and the chip. The metal is removed by the cutting edge of a tool which shears off a chip from the workpiece in metal machining. The majority of the energy deploy for cutting is changed into heat in the primary and secondary shear zones. The energy released in the primary shear zone cannot be avoided. It is occurring because the friction and resulting heat between the tool and the workpiece in the secondary shear zone causes both the tool and the chip to warm. In addition, sliding of the tool flank face on the machined surface in the tertiary shear zone generates friction and heat and could cause flank wear on the flank face $[13,14]$. Formation of the chip depends on the type of material being machined and the cutting conditions of the operation [15]. 


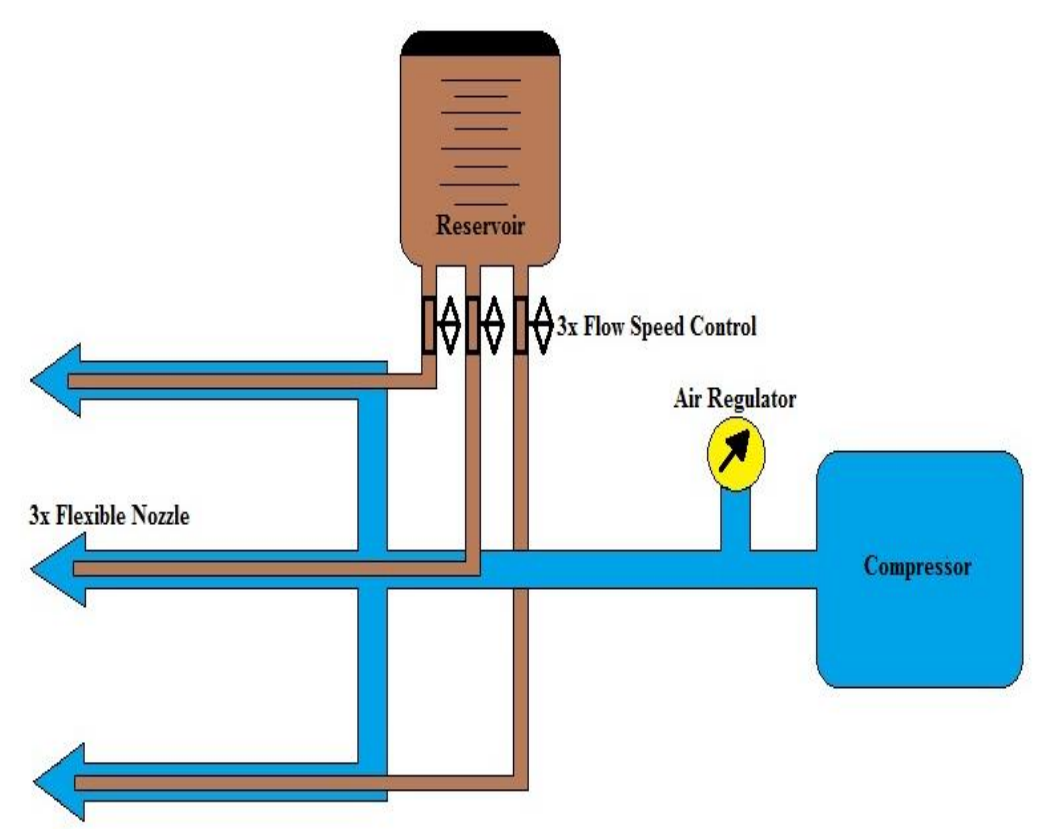

Figure 1. Schematic diagram of components for portable MQL applicator.

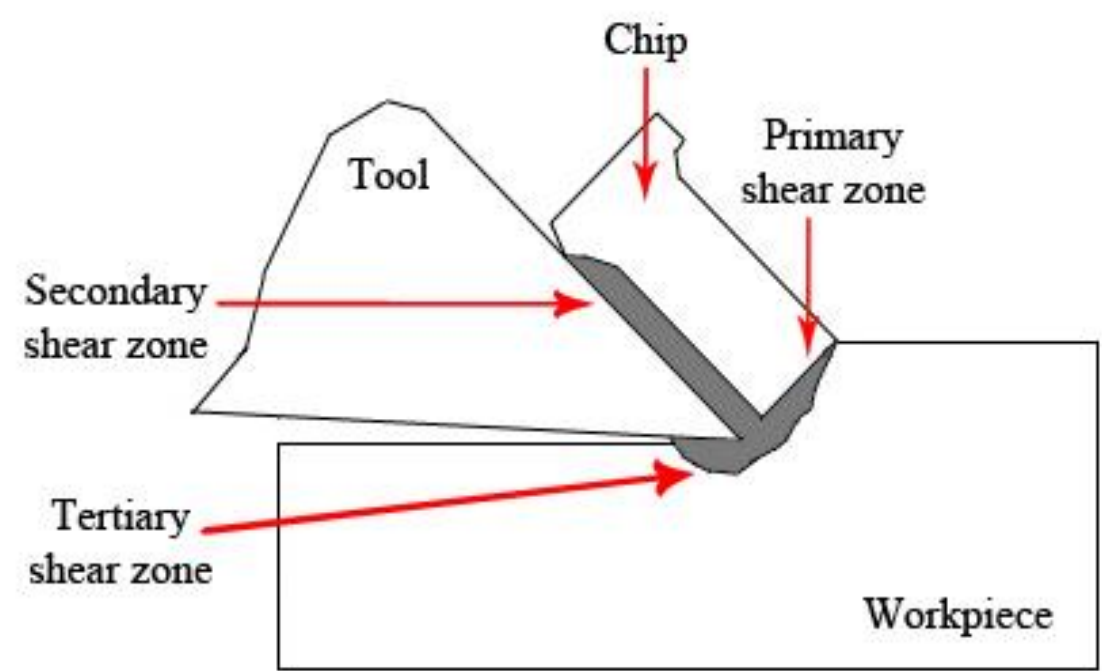

Figure 2. Regions of heat generation in machining.

\section{EXPERIMENTAL PROCEDURE}

The experiments were performed on CNC lathe machine. The lubricant for the Minimum Quantity Lubrication (MQL) employed in the experiments was $100 \%$ natural biodegradable fluid derived from renewable vegetable products. The fluid appearance was yellowish, density of approximate $890 \mathrm{~kg} / \mathrm{m}$ and viscosity of $10 \mathrm{~mm} / \mathrm{s}$. It will not irritate machinist's skin or stain parts, and will not oxidize or leave sticky residue. MQL applicator was mounted on the right hand side of the CNC lathe machine at a location higher than the cutting height. Two flow rate were considered: $\dot{V}(50$ and $100 \mathrm{ml} / \mathrm{h})$. 
The flexible nozzles were directed towards the cutting zone as exhibited in Figure 3 (a) and (b) respectively. Air pressure of 5 bar was employed, as suggested by Boubekri, Shaikh, \& Foster [9].

A TiAIN coated carbide cutting tool CNMG 1204 08-QM 1005 mounted on a standard tool holder has been chosen for the experiments. The tool was $80^{\circ}$ rhombus shapes, nose radius of $0.80 \mathrm{~mm}$ and cutting rake angle of $-6^{\circ}$. All experiments were carried out on nickel-based alloy Inconel 718 cylinder bar (103 mm diameter and 157 $\mathrm{mm}$ long). The standard chemical composition and mechanical properties of the workpiece are tabulated in Tables 1 and 2, respectively [16, 17]. The machining parameters of the finish turning are cutting conditions (MQL $50 \mathrm{ml} / \mathrm{h}, \mathrm{MQL} 100 \mathrm{ml} / \mathrm{h}$ ), cutting speed, Vc $(90,120,150 \mathrm{~m} / \mathrm{min})$, feed rate, $\mathrm{f}(0.10,0.15 \mathrm{~mm} / \mathrm{rev})$ and depth of cut, $\mathrm{d}(0.30,0.50 \mathrm{~mm})$. The selective machining parameters are adopted based upon from previous research in which it was observed the importance of these parameters on the tool wear, tool life, surface roughness, and material removal rate [18]. Dry machining was done to compare the outcome result with MQL machining.

The workpiece was pre-machined at thickness of $2 \mathrm{~mm}$ on every trial run to remove any surface defects that can adversely affect the machining result. The criteria of tool life were set at the average flank wear of $0.3 \mathrm{~mm}$. The average of flank wear, $\mathrm{Vb}$ was measured using a Mitutoyo Tool Maker Microscope with 20x magnification. The tool failure is determined when the measured wear has reached flank wear $\mathrm{Vb}$ of 0.30 $\mathrm{mm}$, as recommended by ISO 3685:1993. The experimental study was performed using Full Factorial Design with 36 runs based on combinations of parameters with a new cutting tool every run, to ensure reliability of the data.

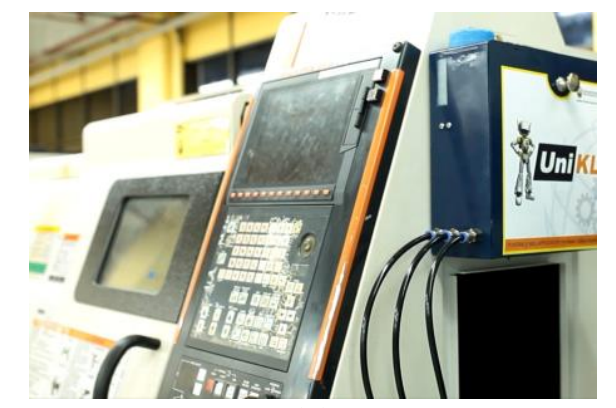

(a)

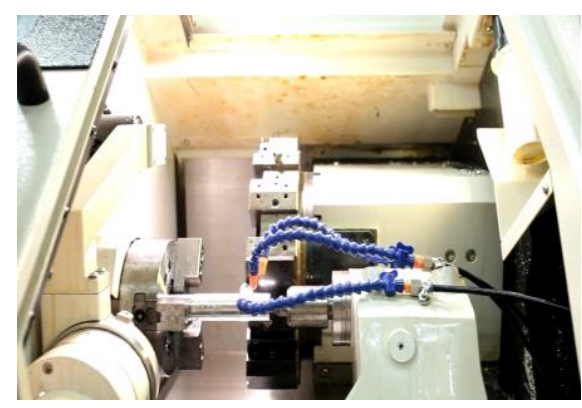

(b)

Figure 3. (a) Portable MQL applicator was installed on the CNC lathe machine (b) nozzle orientation.

Table 1 Inconel 718 composition (wt. \%) [16, 17].

\begin{tabular}{ccccccccccc}
\hline $\mathrm{C}$ & $\mathrm{Mn}$ & $\mathrm{Si}$ & $\mathrm{S}$ & $\mathrm{Cr}$ & $\mathrm{Fe}$ & $\mathrm{Mo}$ & $\mathrm{Nb} \& \mathrm{Ta}$ & $\mathrm{Ti}$ & $\mathrm{Al}$ & $\mathrm{Cu}$ \\
\hline 0.08 & 0.35 & 0.35 & 0.15 & 18.6 & 17.8 & 3.1 & 5.0 & 0.9 & 0.5 & 0.3 \\
\hline
\end{tabular}

Table 2 Mechanical properties of Inconel $718[16,17]$.

\begin{tabular}{ccccccc}
\hline $\begin{array}{c}\text { Tensile } \\
\text { strength } \\
(\mathrm{MPa})\end{array}$ & $\begin{array}{c}\text { Yield } \\
\text { strength } \\
(\mathrm{MPa})\end{array}$ & $\begin{array}{c}\text { Elastic } \\
\text { modulus } \\
(\mathrm{GPa})\end{array}$ & $\begin{array}{c}\text { Hardness } \\
(\mathrm{HV} \mathrm{150)})\end{array}$ & $\begin{array}{c}\text { Density } \\
\left(\mathrm{g} / \mathrm{cm}^{3}\right)\end{array}$ & $\begin{array}{c}\text { Melting } \\
\text { point } \\
\left({ }^{\circ} \mathrm{C}\right)\end{array}$ & $\begin{array}{c}\text { Thermal } \\
\text { conductivity } \\
(\mathrm{W} / \mathrm{mK})\end{array}$ \\
\hline 1310 & 1110 & 206 & 370 & 8.19 & 1300 & 11.2 \\
\hline
\end{tabular}




\section{RESULTS AND DISCUSSION}

Tool life decreases with any increase in cutting speed, feed rate and depth of cut. It was reported, a maximum tool life of $14.45 \mathrm{~min}$ was obtained at low combination of cutting speed of $90 \mathrm{~m} / \mathrm{min}$, feed rate of $0.10 \mathrm{~mm} / \mathrm{rev}$ and depth of cut $0.30 \mathrm{~mm}$ under MQL 50 $\mathrm{ml} / \mathrm{h}$. Figure 4 (a) and (b) exhibits the tool flank wear on the cutting tool under dry machining and MQL $50 \mathrm{ml} / \mathrm{h}$, respectively at low combination of cutting parameters. It can be observed that wear under MQL $50 \mathrm{ml} / \mathrm{h}$ has a much more uniform than dry machining due to the presence of aerosol form to the cutting zone. The shortest tool life was $2.17 \mathrm{~min}$ at a high combination of cutting speed of $150 \mathrm{~m} / \mathrm{min}$, feed rate of 0.15 $\mathrm{mm} / \mathrm{rev}$ and depth of cut of 0.50 and $0.30 \mathrm{~mm}$ under MQL 50 and $100 \mathrm{ml} / \mathrm{h}$ as depicted in Figure 5 (b) and (c) respectively. It shows that the tool life for MQL 50 and MQL $100 \mathrm{ml} / \mathrm{h}$ are better compared to dry machining due to the impact of MQL onto the TiAIN coated carbide was reflected in the lower wear of the initial stage and the prolonged duration of the steady wear stage. This result also was similar that reported by Qin et al. [19] and Elmunafi et al. [1] when turning titanium alloy TC11 and hardened steel (AISI 4340) under MQL technique respectively. Nevertheless, the trend line in MQL 50 and MQL $100 \mathrm{ml} / \mathrm{h}$ was seen almost same but differently with dry machining. This phenomenon is occurring due to the lubrication effect of both MQL that affecting to the change of microstructure of machined surface. Moreover, the MQL applicator was able to penetrate deep into the tool-chip and tool-workpiece interface which supports the coated carbide tool to perform better at high cutting condition and resulted in longer tool life.

Material removal rate (MRR) is defined as the volume of the chips produced from a machined workpiece in a minute. Normally, the higher value is assumed as good indicators affecting the productivity in term of saving the machining time. Figure 6 demonstrates the variation of the material removal rate with cutting speed under dry, MQL $50 \mathrm{ml} / \mathrm{h}$ and MQL $100 \mathrm{ml} / \mathrm{h}$ conditions. The cutting with speed of $150 \mathrm{~m} / \mathrm{min}$, feed of $0.15 \mathrm{~mm} / \mathrm{rev}$ and depth of cut of $0.50 \mathrm{~mm}$ under MQL $50 \mathrm{ml} / \mathrm{h}$ represent that maximum MRR of $16.70 \mathrm{~cm}^{3} / \mathrm{min}$ compare as dry and MQL $100 \mathrm{ml} / \mathrm{h}$. Minimum MRR which is $2.70 \mathrm{~cm}^{3} / \mathrm{min}$ was obtained at cutting speed, feed rate and depth of cut, which are $90 \mathrm{~m} / \mathrm{min}, 0.10 \mathrm{~mm} / \mathrm{rev}$ and $0.30 \mathrm{~mm}$, respectively under MQL $50 \mathrm{ml} / \mathrm{h}$. Thus, the best alternate conditions chosen were cutting speed of $150 \mathrm{~m} / \mathrm{min}$, feed rate of 0.15 $\mathrm{mm} / \mathrm{rev}$ and depth of cut of $0.50 \mathrm{~mm}$ under MQL $50 \mathrm{ml} / \mathrm{h}$ for productivity purpose. This condition is parallel with the literature as stated by Yildirim et al. [20] that the flow rate of $50 \mathrm{ml} / \mathrm{h}$ was effective in which to form the film layer to extend tool life with reducing of the friction at the cutting tool and workpiece interface.

From Figure 5 (a) and 6 (a), the tool life and MRR growth were seen increased substantially under dry machining at a cutting speed of $120 \mathrm{~m} / \mathrm{min}$, feed rate of 0.10 and $0.15 \mathrm{~mm} / \mathrm{rev}$ and depth of cut of 0.30 and $0.50 \mathrm{~mm}$ for tool life and MRR, respectively. This could be due to the occurrence of thermal shock on the cutting edge. Thermal shock occurs due to high temperatures resulting from high cutting speed and high temperature degree during the machining process which able lead the tool life and MRR growth. 


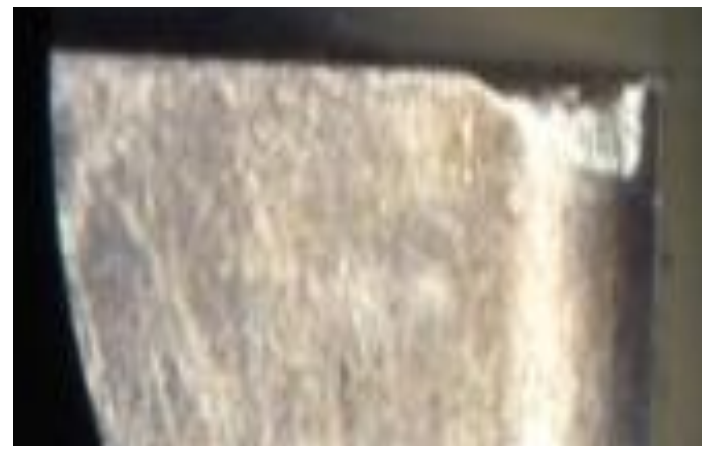

(a)

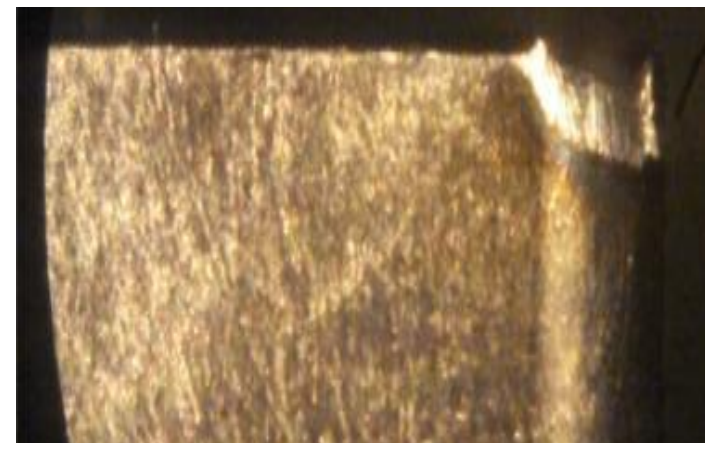

(b)

Figure 4. Tool flank wear at $\mathrm{Vc}=90 \mathrm{~m} / \mathrm{min}, \mathrm{f}=0.1 \mathrm{~mm} / \mathrm{rev}, \mathrm{d}=0.3 \mathrm{~mm}$ under two different environments (a) dry machining (b) MQL $50 \mathrm{ml} / \mathrm{h}$.

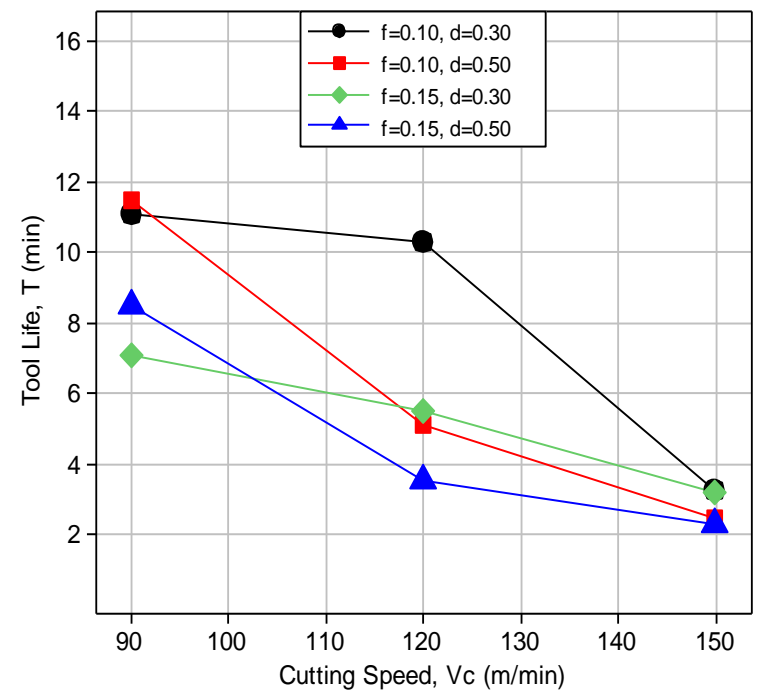

(a)

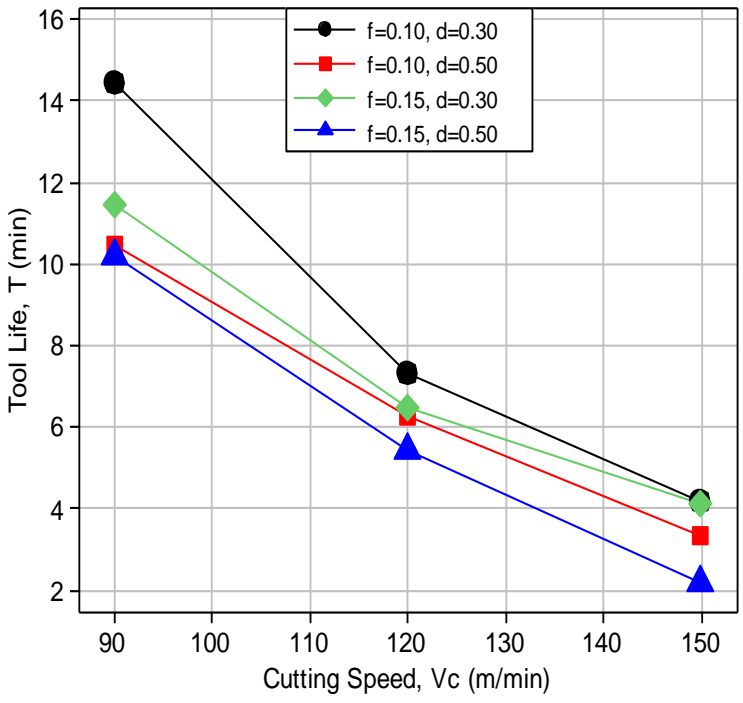

(b)

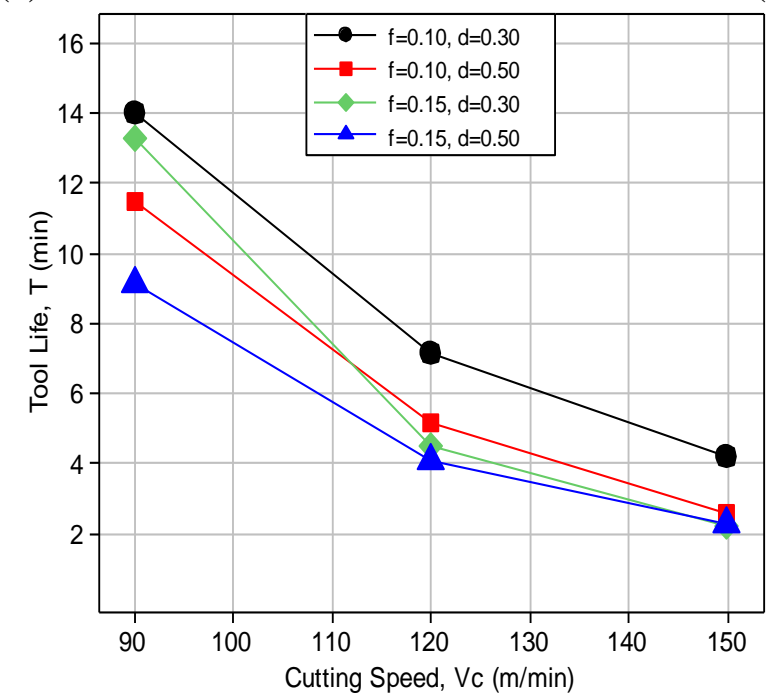

(c)

Figure 5. Tool life against cutting speed at different feed rate and depth of cut under three different environments (a) dry machining (b) MQL $50 \mathrm{ml} / \mathrm{h}$ (c) MQL $100 \mathrm{ml} / \mathrm{h}$. 


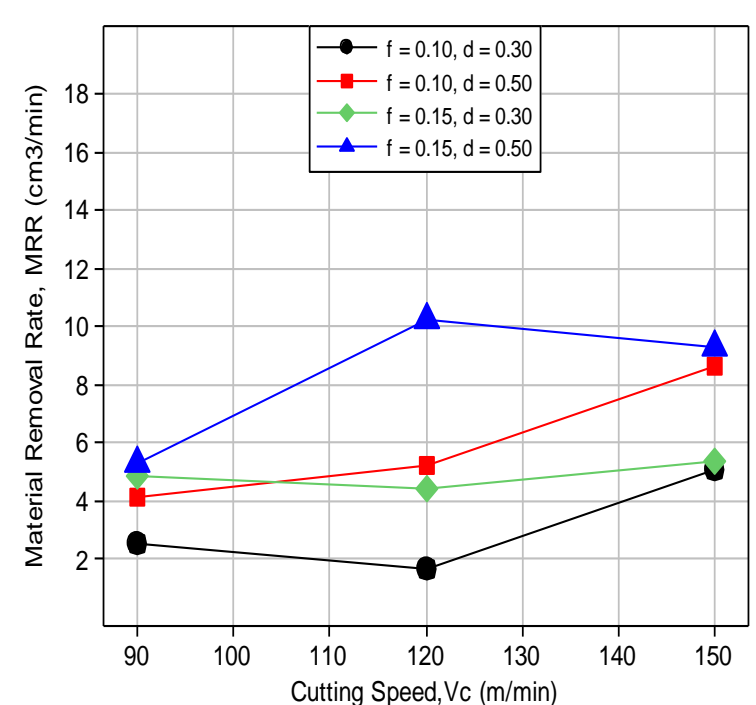

(a)

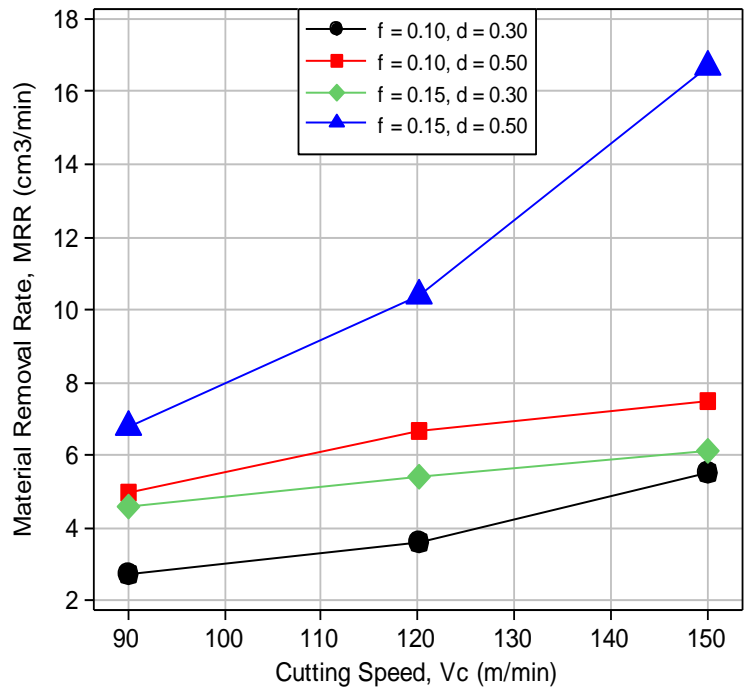

(b)

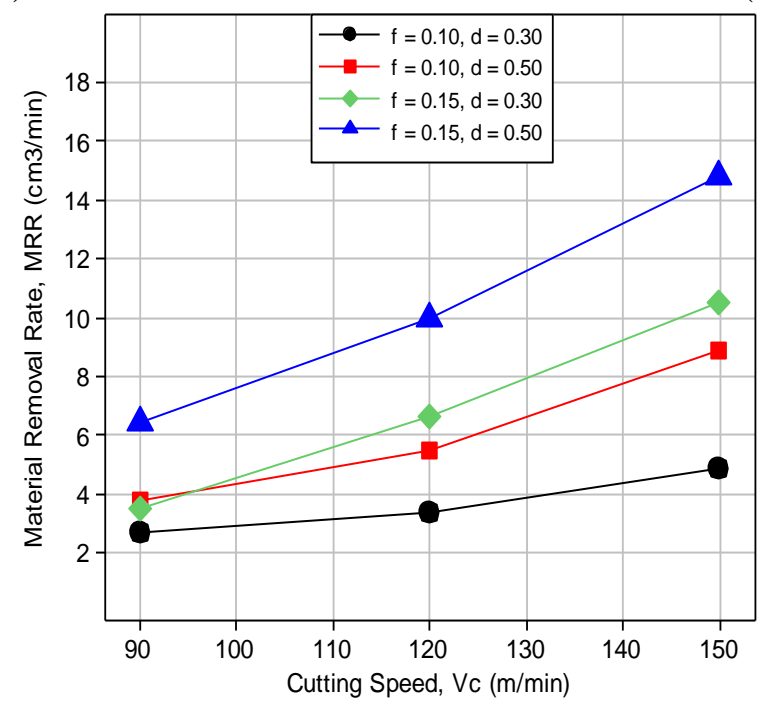

(c)

Figure 6. Material removal rate against cutting speed at different feed rate and depth of cut under three different environments (a) dry machining (b) MQL $50 \mathrm{ml} / \mathrm{h}$ (c) MQL $100 \mathrm{ml} / \mathrm{h}$.

\section{CONCLUSION}

The experimental study using the Portable MQL applicator was carried out under high speed turning parameters and yields the following conclusion:

- Tool life has shown an improvement of 50\% and 38\% using both MQL 50 and MQL $100 \mathrm{ml} / \mathrm{h}$ respectively. Portable MQL applicator gave better tool life compared to dry machining when turning Inconel 718 with coated carbide cutting tools because it is improving the chip-tool interaction and maintained sharpness of the tool tip.

- Productivity in term of better MRR was achieved at cutting speed of $150 \mathrm{~m} / \mathrm{min}$, feed rate of $0.15 \mathrm{~mm} / \mathrm{rev}$ and depth of cut of $0.50 \mathrm{~mm}$ under MQL $50 \mathrm{ml} / \mathrm{h}$. The 
results were better when compared with dry and MQL $100 \mathrm{ml} / \mathrm{h}$ due to improved lubrication effects.

- Use of MQL $50 \mathrm{ml} / \mathrm{h}$ presented an overall outstanding performance for tool life and MRR under disparate parameters. MQL $50 \mathrm{ml} / \mathrm{h}$ was recommended for turning of Inconel 718 because it possesses an effective lubrication aerosol rate.

\section{ACKNOWLEDGEMENTS}

The authors would like to thank Universiti Kuala Lumpur Short Term Research Grant (STR 15051) for financial assistance to carry out this research works.

\section{REFERENCES}

[1] Elmunafi MHS, Noordin MY, Kurniawan D. Tool life of coated carbide cutting tool when turning hardened stainless steel under minimum quantity lubricant using castor oil. Procedia Manufacturing. 2015;2:563-567.

[2] Najiha MS, Rahman MM, Kadirgama K. Experimental investigation and optimization of minimum quantity lubrication for machining of AA6061-T6. International Journal Automotive and Mechanical Engineering. 2015;11:27222737.

[3] Debnath S, Reddy MM, Yi QS. Environmental friendly cutting fluids and cooling techniques in machining: a review. Journal of Cleaner Production. 2014;83:3347.

[4] Cakir A, Yagmur S, Kavak N, Kucukturk G, Seker U. The effect of minimum quantity lubrication under different parameters in the turning of AA7075 and AA2024 aluminium alloys. International Journal of Advance Manufacturing Technology. 2016;84:2515-2521.

[5] Yazid MZA, Cheharon CH, Ghani JA, Ibrahim GA, Said AYM. Surface integrity of Inconel 718 when finish turning with PVD coated carbide tool under MQL. Procedia Engineering. 2012;19:396-401.

[6] Chandra Behera B, Ghosh S, Venkateswara Rao P. Effects on forces and surface roughness during machining inconel 718 alloy using minimum quantity lubrication. All India Manufacturing Technology, Design and Research Conference. 2014:1-6.

[7] Upadhyay V, Jain PK, Mehta NK. Minimum Quantity Lubrication Assisted Turning - An Overview. Daaam International Science Book 2012. 2012:463-478.

[8] Vishwakarma A, Jain S, Sharma PK. Analysis of effect of minimum quantity lubrication on different machining parameters cutting force, surface roughness and tool wear by hard turning of AISI-4340 Alloy Steel a review. International Journal of Advanced Engineering Research and Technology. 2014;2:344-354.

[9] Boubekri N, Shaikh V, Foster PR. A technology enabler for green machining: minimum quantity lubrication (MQL). Journal of Manufacturing Technology Management. 2010;21:556-566.

[10] Ahmad-yazid A, Taha Z, Almanar IP. A review of cryogenic cooling in high speed machining ( HSM ) of mold and die steels. Review Literature and Arts of the Americas. 2010;5:412-427.

[11] Shokrani A, Dhokia V, Newman ST. Environmentally conscious machining of difficult-to-machine materials with regard to cutting fluids. International Journal of Machine Tools and Manufacture. 2012;57:83-101. 
[12] Singh, Talwinder Singh, Pragat Dureja, JS Dogra M. A review of near dry machining/minimum quantity lubrication machining of difficult to machine alloys. International Journal of Machining and Machinability of Materials. 2016;18:213-251.

[13] Groover MP. Fundamentals of Modern Manufacturing. 2010.

[14] Shah SR. Extraction of electrical energy from heat produced during metal cutting operation on lathe by using thermocouples. International Journal of Engineering Research and Applications. 2015;5:24-35.

[15] Kadirgama NHRMMRK. Cutting force and chip formation in end milling operation when machining nickel-based superalloy, Hastelloy C-2000. Journal of Mechanical Engineering and Sciences. 2017;11:2539-2551.

[16] Ramamoorthy B, Vijayaraghavan L. Effect of high speed cutting parameters on the surface characteristics of Superalloy Inconel 718. Proceedings of The World Congress on Engineering 2010. 2010;3.

[17] Thamizhmanii S, Rosli, S.Hasan. A study of minimum quantity lubrication on Inconel 718 steel. Archives of Materials Science and Engineering. 2009;39:3844.

[18] Abu Yazid MZ. Kebolehmesinan Inconel 718 pada pemesinan laju tinggi dalam keadaan kuantiti pelincir minima. 2014:281.

[19] Qin S, Li Z, Guo G, An Q, Chen M, Ming W. Analysis of minimum quantity lubrication (MQL) for different coating tools during turning of TC11 titanium alloy. Journal of Materials Science. 2016;9.

[20] Yıldırım ÇV, Kıvak T, Sarıkaya M, Erzincanlı F. Determination of MQL parameters contributing to sustainable machining in the milling of Nickel-Base Superalloy Waspaloy. Arabian Journal for Science and Engineering. 2017;42:4667-4681. 